\title{
Review:
}

\section{Weathering the storm: COVID-19 infection in patients with hematological malignancies*}

\author{
Lin-qin WANG ${ }^{\S 1,2,3,4}$, Elaine TAN SU YIN ${ }^{\S 1,2,3,4}$, Guo-qing WEI ${ }^{1,2,3,4}$, \\ Yong-xian $\mathrm{HU}^{\dagger 1,2,3,4}$, Arnon NAGLER ${ }^{\dagger 5}$, He HUANG ${ }^{\dagger 1,2,3,4}$ \\ ${ }^{1}$ Bone Marrow Transplantation Center, the First Affiliated Hospital, School of Medicine, Zhejiang University, Hangzhou 310003, China \\ ${ }^{2}$ Zhejiang Province Engineering Laboratory for Stem Cell and Immunity Therapy, Hangzhou 310058, China \\ ${ }^{3}$ Institute of Hematology, Zhejiang University, Hangzhou 310058, China \\ ${ }^{4}$ Zhejiang Laboratory for Systems \& Precision Medicine, Zhejiang University Medical Center, Hangzhou 310058, China \\ ${ }^{5}$ Hematology and Bone Marrow Transplantation Division, Chaim Sheba Medical Center, Tel-Hashomer 52621, Israel \\ †E-mail: huyongxian2000@aliyun.com; Arnon.Nagler@sheba.health.gov.il; huanghe@zju.edu.cn \\ Received Aug. 2, 2020; Revision accepted Sept. 16, 2020; Crosschecked Nov. 11, 2020
}

\begin{abstract}
The coronavirus disease 2019 (COVID-19) is an emerging infectious disease caused by severe acute respiratory syndrome coronavirus 2 (SARS-CoV-2). Within a matter of months, this highly contagious novel virus has led to a global outbreak and is still spreading rapidly across continents. In patients with COVID-19, underlying chronic diseases and comorbidities are associated with dismal treatment outcomes. Owing to their immunosuppressive status, patients with hematological malignancies (HMs) are at an increased risk of infection and have a worse prognosis than patients without HMs. Accordingly, intensive attention should be paid to this cohort. In this review, we summarize and analyze specific clinical manifestations for patients with coexisting COVID-19 and HMs. Furthermore, we briefly describe customized management strategies and interventions for this susceptible cohort. This review is intended to guide clinical practice.
\end{abstract}

Key words: Coronavirus disease 2019 (COVID-19); Hematological malignancies; Immunosuppressive status; Management strategies; Treatment regimen

https://doi.org/10.1631/jzus.B2000423

CLC number: R73; R511

\section{Introduction}

The coronavirus disease 2019 (COVID-19) has spread worldwide in the past ten months. By Oct. 9, 2020, according to the World Health Organization (2020),

\footnotetext{
${ }^{\ddagger}$ Corresponding authors

$\S$ The two authors contributed equally to this work

* Project supported by the National Natural Science Foundation of China (Nos. 81770201 and 81730008)

(i) ORCID: He HUANG, https://orcid.org/0000-0002-2723-1621; Arnon NAGLER, https://orcid.org/0000-0002-0763-1265; Yong-xian HU, https://orcid.org/0000-0001-9564-1852; Lin-qin WANG, https://orcid. org/0000-0003-4104-6120; Elaine TAN SU YIN, https://orcid.org/00000001-7268-8455

(C) Zhejiang University and Springer-Verlag GmbH Germany, part of Springer Nature 2020
}

a total of 36361054 cumulative confirmed cases and 1056186 deaths had been documented globally in 216 countries and territories across six continents. Recent epidemiological study has revealed that the highly infectious causal pathogen, severe acute respiratory syndrome coronavirus 2 (SARS-CoV-2), is commonly transmitted through respiratory droplets and close contact (Gu et al., 2020). It has also been detected in the sputum, blood, stool (Gu et al., 2020), urine (Jones et al., 2020), and even tears (Xia et al., 2020). At the molecular level, SARS-CoV-2 can enter host cells via interacting with angiotensin-converting enzyme 2 (ACE2) receptors located in various organs (Hamming et al., 2004; Zhou P et al., 2020), and therefore, could induce multiple-organ manifestations 
of infection (Gavriatopoulou et al., 2020). The severity and clinical outcomes of COVID-19 vary among individuals. Up to now, an advanced age, high sequential organ failure assessment score, high D-dimer level on admission, and preexisting chronic diseases have been recognized as risk factors for dismal outcomes (Wang XH et al., 2020; Zhou F et al., 2020). In particular, patients with cancer have a remarkably elevated risk of COVID-19 and poorer outcomes than those in non-cancer cohorts, which can be explained by the systemic immunosuppressive state caused by the malignancies and anti-cancer therapies (Liang et al., 2020).

Hematological malignancies (HMs) are a group of heterogeneous blood diseases, including leukemias, lymphomas, and multiple myelomas (MMs) (Li et al., 2018). According to the most recent statistics, both leukemia and non-Hodgkin lymphoma are among the top ten cancers in terms of incidence and death rates (Siegel et al., 2019). As cancer progresses, malignant cells proliferate extensively and inhibit normal hematopoiesis. The suppression of leukopoiesis confers increased susceptibility to several infections, such as bacterial, fungal, and viral infections (Busca, 2012). Though HMs remain challenging, the survival period and quality of life of patients with HMs have improved remarkably as a result of the introduction of chemotherapy, targeted therapy, monoclonal antibodies, and lately cell-based immunotherapy. However, these anti-cancer therapies might also expose patients to a higher risk of infection (Byrne et al., 2017).

Amid the COVID-19 outbreak, clinicians need to optimize the clinical management of HM patients in terms of treatment regimens, preventive measures for infection, clinical trials of novel therapies, and long-term follow-up. Recently, detailed case reports and cohort studies of COVID-19 in patients with preexisting HMs have become increasingly available in databases like PubMed, Web of Science, and medRxiv. Given the unfavorable outcomes of this susceptible group, strict vigilance is necessary to recognize and differentiate clinical manifestations, radiologic patterns, and laboratory findings. Moreover, the timely detection of COVID-19 and positive interventions are not only necessary to improve the survival rate of patients with HMs, but also to limit transmission among patients and caregivers. In this review, we outline recent reports of patients with coexisting COVID-19 and HMs. Also, we summarize the specific clinical manifestations. Based on recent guidelines and clinical experience, we have compiled a set of management strategies for HM patients and interventional strategies for patients with HMs and COVID-19.

\section{Regional reports of SARS-CoV-2 infections in patients with HMs}

Owing to the characteristics of COVID-19 in HM cohorts, increasing numbers of case reports, large-cohort studies, and scattered clinical experiences have recently been presented. In this section, we summarize details of recent cases (Table 1) and provide an overview of several large-cohort studies.

In Wuhan, China, 128 hospitalized patients with HMs and 226 caregivers from two centers were included in a cohort study (He et al., 2020). The calculated incidences of SARS-CoV-2 infection in HM and caregiver cohorts were $10 \%$ and $7 \%$, respectively. Though no significant difference was found in terms of prevalence, subjects with HMs tended to develop severe COVID-19. Based on the data of 530 individuals with chronic myeloid leukemia (CML), another local study group in Hubei Province reported a SARS-CoV-2 infection prevalence of $0.9 \%$ in patients and $0.1 \%$ in healthy individuals (Baumann et al., 2020). Note that advanced phase CML could enhance the risk of COVID-19, even if patients attained a complete cytogenetic response or significant molecular response.

Meanwhile, in the UK, Cook et al. (2020) conducted a real-world assessment, focusing on the clinical impact of COVID-19 in individuals with MMs. The risk of death was found to be significantly associated with male gender, advancing age, and other comorbidities. The authors also noted that patients with relapsed or refractory MM might be at the highest risk of dismal outcomes once infected. Moreover, multicenter retrospective research in China that focused on the same topic reported that HM patients have a poorer prognosis than solid tumor patients (Yang et al., 2020).

The European Myeloma Network (Terpos et al., 2020b) and Malard and Mohty (2020) published detailed management strategies for MM during the COVID-19 pandemic. In France, Malard et al. (2020) studied consecutive adult patients with hematologic disorders at the Hematology Department of the Saint-Antoine 


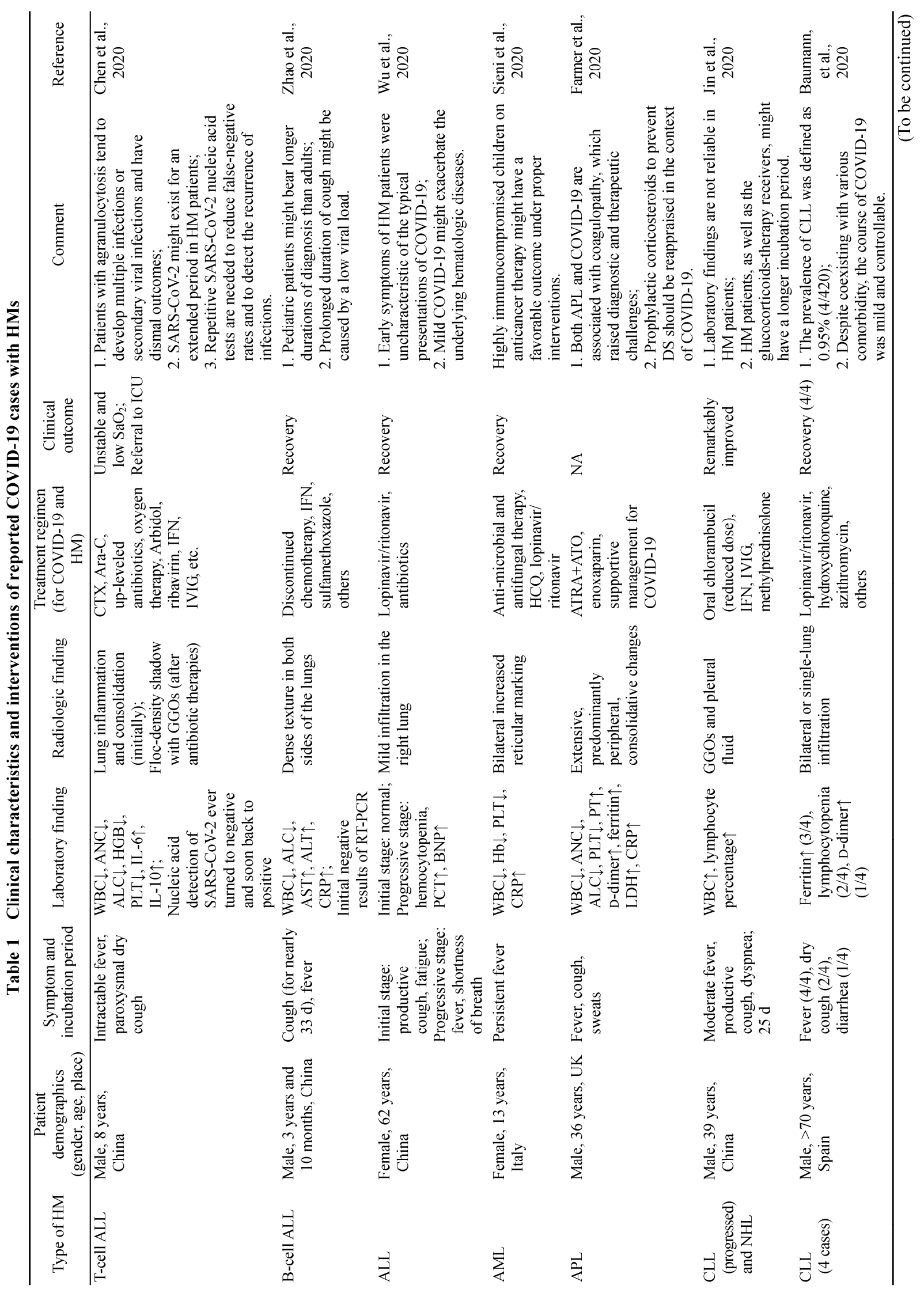




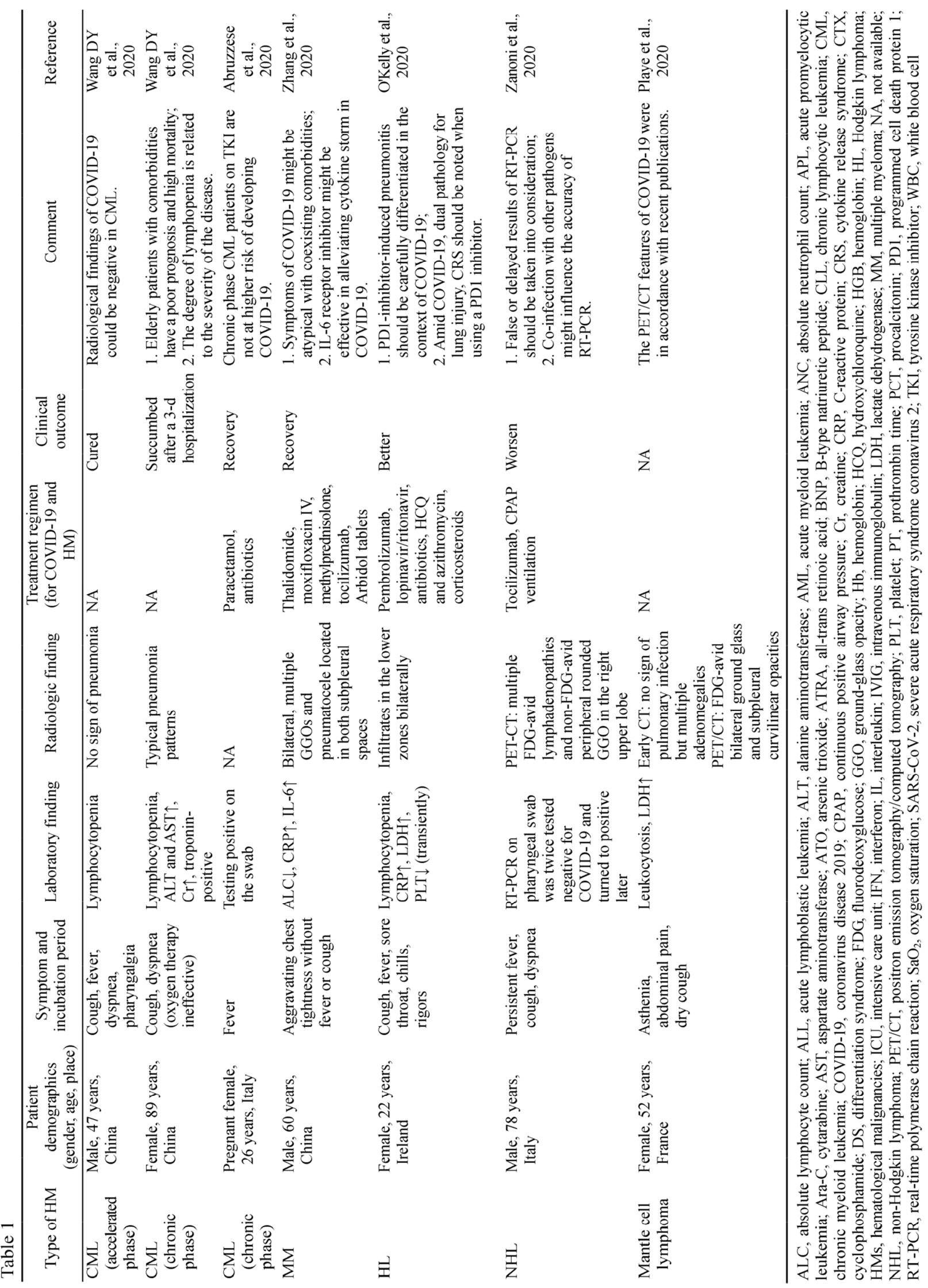


Hospital, beginning on Mar. 9, 2020. After nearly one month, 25 patients with hemopathies had confirmed COVID-19. In this cohort, fever (22/25), cough (19/25), and shortness of breath $(19 / 25)$ were the most common complaints at diagnosis. Complementary examinations were also typical, for example, lymphopenia (23/25) and bilateral ground-glass opacities (25/25). The HM cohort was at a higher risk of developing severe COVID-19 with acute respiratory distress syndrome. Within this cohort, patients with MM accounted for a high proportion, emphasizing the impact of steroidinvolved chemotherapy.

Foà et al. (2020) collected data on adult patients with acute lymphoblastic leukemia (ALL) from 40 hematological centers in Italy during the COVID-19 outbreak. Notably, in the Philadelphia chromosomepositive $(\mathrm{ph}+)$ cohort, only one individual had verified COVID-19, and one was symptomatic but tested negative. The low infection rate supported the effectiveness of the tyrosine kinase inhibitor (TKI)-based "soft" approach for the treatment of $\mathrm{ph}+\mathrm{ALL}$. Moreover, the effectiveness of this regimen has been identified in GIMEMA (Gruppo Italiano Malattie Ematologiche dell'Adulto) nationwide trials. More importantly, amid the COVID-19 pandemic, this regimen has reduced the hospitalization days and enabled home-based treatment.

Subsequently, in Barcelona, Spain, 804 chronic lymphocytic leukemia (CLL) patients were registered, 420 of whom maintained follow-up. Of this CLL cohort, only four patients $(0.95 \%)$ were diagnosed with symptomatic COVID-19. The details of the four infected individuals with CLL are summarized in Table 1. These published case reports and cohort studies were performed at different research centers, with differences in various factors, such as medical level and treatment planning. Thus, an overview of their experiences could provide insight into optimal choices for patient care.

\section{Specific clinical manifestations, radiologic patterns, and laboratory findings in patients with COVID-19 and HMs}

\subsection{Clinical manifestations}

In 2002 and 2003, most patients with SARS had a fever $(99 \%-100 \%)$. In contrast, fever $(43.8 \%$ on admission, $88.7 \%$ during hospitalization) and nonproductive cough $(67.8 \%)$ are not specific symptoms for COVID-19 (Guan et al., 2020; Han et al., 2020). Those asymptomatic SARS-CoV-2 carriers might contribute to the acceleration of COVID-19 transmission. Based on recent literature, patients with HMs are more likely to be asymptomatic carriers presenting with atypical and delayed COVID-19 symptoms. As shown in Table 1, some COVID-19 patients with HMs might experience extended incubation periods (Jin et al., 2020). Patients with HMs, along with COVID-19, might be non-febrile on admission or during the entire period of illness (Zhang et al., 2020). Moreover, mild initial symptoms (e.g., a slight cough, dyspnea, or chest tightness) might be followed by rapid deterioration. Worse still, overlapping clinical manifestations of the infection and tumor would hinder diagnosis, as discussed in detail later.

\subsection{Radiologic findings}

In most patients with COVID-19, the initial radiologic findings show multiple patchy shadows and interstitial changes in the lungs before the appearance of ground-glass opacities (Guan et al., 2020). In HM cohorts, radiologic imaging findings might not be significantly typical or recognizable. Because of their low immunity, lung imaging of patients might initially show mixed lesions of bacterial, viral, or fungal infections. Signs of viral infection would take time to emerge after the administration of antimicrobial and antifungal medications. In immunocompromised patients, the critical viral infection could lead to "extensive white lung," which is caused mainly by the respiratory syncytial virus, cytomegalovirus, or SARS-CoV-2, individually or collectively. In clinical practice, we also discovered that patients with COVID-19 would have radiographic images and patterns of disease progression based on chest imaging (X-ray and computed tomography (CT) scan) similar to those of patients with cytomegalovirus-related pneumonia with diffuse large B-cell lymphoma (Fig. 1). Therefore, besides radiologic imaging, a definite diagnosis would be required with nasopharyngeal swabs or bronchoalveolar lavage samples, testing for COVID-19 and other pathogens.

\subsection{Laboratory tests}

The characteristic laboratory features of COVID-19 include lymphocytopenia, leukopenia, and thrombocytopenia (Guan et al., 2020). However, in patients 


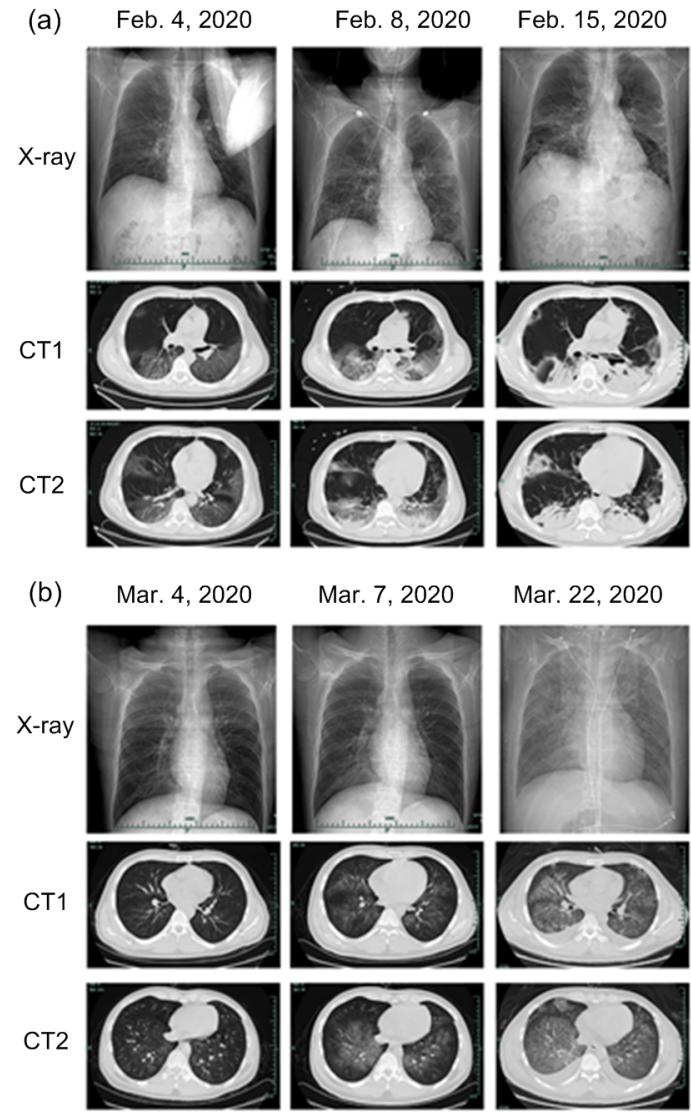

Fig. 1 Comparisons of chest imaging (X-ray and CT scans) of COVID-19 and CMV pneumonia

These two types of pneumonia (COVID-19 vs. CMV) showed a somewhat similar progression in the initial stage, progressive stage, and consolidation stage/diffuse infiltration stage of infection. Initially, both presented with typical GGOs. (a) Chest imaging of COVID-19 pneumonia. A 51-year-old male was confirmed with COVID-19 and received CT scans on 4, 8, and 15 February, 2020. (b) Chest imaging of CMV pneumonia. A 26-year-old male with diffuse large B cell lymphoma (non-GCB, IVB stage) was diagnosed with CMV pneumonia during chemotherapy. He received CT scans on 4, 7, 22 March, 2020. COVID-19, coronavirus disease 2019; CMV, cytomegalovirus; CT, computed tomography; GCB, germinal center B-cell-like lymphoma; GGOs, ground-glass opacities

with HMs, laboratory results are not as reliable as those for COVID-19 patients without such malignancies. Hematological neoplasms and treatment regimens might influence the blood system to variable degrees. For example, leukemia cells could boost leukocyte counts to abnormally high levels, whereas other malignant cells could impair the function of hematopoiesis and leukopoiesis. Moreover, the un- explained phenomenon of "COVID-induced lymphocytosis (CIL)," with remarkably elevated levels of leukocytes and lymphocytes, was observed in patients with CLL (Paneesha et al., 2020). Additionally, highdose chemotherapeutic agents and lymphocyte-targeted immunotherapy would influence normal hematopoiesis and deplete lymphocytes non-selectively. For example, rituximab, an anti-CD20 monoclonal antibody, and chimeric antigen receptor (CAR) T-cell therapy were designed to effectively recognize and lyse malignant and non-malignant B-cells (Freeman and Sehn, 2018; June and Sadelain, 2018).

Furthermore, severe COVID-19 could be characterized by a hyper-inflammatory status with a significant elevation of serum cytokines and chemokines (Mehta et al., 2020). High serum procalcitonin, ferritin, C-reactive protein, lactate dehydrogenase, interleukin-6 (IL-6), and D-dimer levels are associated with a dismal prognosis for COVID-19, prompting timely intervention to improve clinical outcomes (Lagunas-Rangel, 2020; Terpos et al., 2020a).

Undeniably, microbial pathogen detection and serological tests are the most accurate methods to diagnose COVID-19, even in patients with HMs. Using real-time polymerase chain reaction (RT-PCR) and next-generation sequencing, it is possible to identify SARS-CoV-2 nucleic acids from various specimen types like nasopharyngeal swabs, sputum samples, and blood samples. With respect to serological tests, immunoglobulin M (IgM) specific to SARS-CoV-2 can be detected nearly $3 \mathrm{~d}$ after infection, and IgG levels increase four-fold during the recovery phase. However, for subjects with negative RT-PCR results, typical CT patterns could be found in more than $70 \%$ of suspected individuals (Ai et al., 2020). Therefore, it is better to increase the frequency of examination or combine nucleic acid tests with serological tests (or imaging results) to improve the COVID-19 detection rate in patients with HMs.

\section{Clinical diagnostic criteria and differential diagnoses of patients with COVID-19 and HMs}

During the COVID-19 pandemic, clinical diagnostic criteria are essential to differentiate between infected and non-infected cohorts efficiently. In line with the certainty of diagnosis, these criteria divide 
patients into three categories, specifically "surveillance cases," "clinically COVID-19 suspected cases," and “confirmed COVID-19 cases" (Table 2).

In clinical practice, the efficient identification of "suspected cases" is an urgent and challenging issue, especially in HM cohorts, due to diverse manifestations with various confounding factors. Besides SARSCoV-2, pneumonia in patients with HM could be induced by other viruses, fungal pathogens, or even medications. Table 3 clearly describes the similarities and unique features of various types of pneumonia in patients with HMs. According to the Chinese guidelines for COVID-19, suspected cases can be ruled out if an individual tests negative twice in the SARSCoV-2 nucleic acid test and achieves negative serological results $7 \mathrm{~d}$ after disease onset. As a side note, samples for nucleic acid detection should be collected using a throat swab or nasal swab (at longer than a 1-d interval).

Another significant issue is the partial overlap between the common complaints of patients with
HMs and patients with COVID-19. Fever, as a systemic warning symptom of COVID-19, is commonly observed in the hematology department. The causative factors, including infection, cancer, and treatment, should be dissected with meticulous attention (Table 4). Organ-specific manifestations of COVID-19 also partly resemble the symptoms of HMs. In a large retrospective study, the neurological complication of COVID-19 was observed in over $36.4 \%$ of infected patients, and $24.8 \%$ of infected patients presented symptoms from the central nervous system (CNS) (Gavriatopoulou et al., 2020; Mao et al., 2020). The most common CNS symptoms were dizziness and headache, which overlapped with the CNS involvement of leukemia or myeloma in patients with HMs. Kidney involvement, a typical complication of $\mathrm{MM}$, is also common in SARS-CoV-2-infected individuals. For instance, a large prospective study, which involved both moderate and severe COVID-19 cases, demonstrated that $43.9 \%$ presented with proteinuria and $26.7 \%$ with hematuria on admission (Boulware et al., 2020; Gavriatopoulou

Table 2 Stratified diagnosis criteria of SARS-CoV-2 infection in patients with HMs

\begin{tabular}{|c|c|}
\hline Case category & Criteria for diagnosis \\
\hline Surveillance $^{\mathrm{a}}$ & $\begin{array}{l}\text { 1. The patient presents with systemic or respiratory signs and symptoms, such as fever, fatigue, nausea, } \\
\text { vomiting, and diarrhea. } \\
\text { 2. The patient had a close contact with clinically suspected or confirmed COVID-19 cases. }\end{array}$ \\
\hline Suspected $^{\mathrm{b}}$ & $\begin{array}{l}\text { 1. History of exposure: } \\
\text { - The patient had a living history or travel history in and around areas with high COVID-19 prevalence or } \\
\text { stayed in the community with suspected COVID-19 cases. } \\
\text { - The patient had close contact with individuals who had been to areas with high COVID-19 prevalence or } \\
\text { the community with suspected COVID-19 symptoms. } \\
\text { - The patient was from one of the COVID-19 clusters. } \\
\text { - The patient had a contact history with confirmed COVID-19 patients. } \\
\text { 2. Clinical manifestations: } \\
\text { - The patient presents with fever or respiratory symptoms like non-productive cough, dyspnea, and chest } \\
\text { tightness. } \\
\text { - The imaging test of the patient shows pneumonia features with multiple spot shadows and interstitial } \\
\text { changes. It could progress into multiple infiltration shadows on bilateral lung and pulmonary consolida- } \\
\text { tion in severe cases; however, pleural effusion is rare. } \\
\text { - The total leukocyte count, granulocyte count, and (or) lymphocyte count could be reduced. } \\
\text { - When there are no definite or convincing etiologies to explain the clinical manifestations thoroughly. }\end{array}$ \\
\hline Confirmed $^{\mathrm{c}}$ & $\begin{array}{l}\text { 1. Positive nucleic acid detection of the SARS-CoV-2 from the samples (respiratory tract secretion, blood, } \\
\text { etc.) by RT-PCR; } \\
\text { 2. Sequencing of the SARS-CoV-2 viral genomes from samples of the respiratory tract or blood; } \\
\text { 3. Both IgM and IgG serological results of SARS-CoV-2 test positive. }\end{array}$ \\
\hline
\end{tabular}

${ }^{a}$ Cases that are consistent with one of the diagnostic items should be kept under clinical observation. ${ }^{b}$ Suspected cases refer to any individuals with a confirmed history of exposure, accompanied by two of the clinical manifestations. ${ }^{\circ}$ Cases that are compatible with each of the diagnostic items can be diagnosed as a confirmed case of COVID-19. COVID-19, coronavirus disease 2019; HMs, hematological malignancies; Ig, immunoglobulin; SARS-CoV-2, severe acute respiratory syndrome coronavirus 2; RT-PCR, real-time polymerase chain reaction. Stratified diagnosis criteria refer to Liang et al. (2020), China National Health Commission (2020), and Subspecialty Group of Hematology and Oncology, Society of Pediatrics of Hubei (2020) 


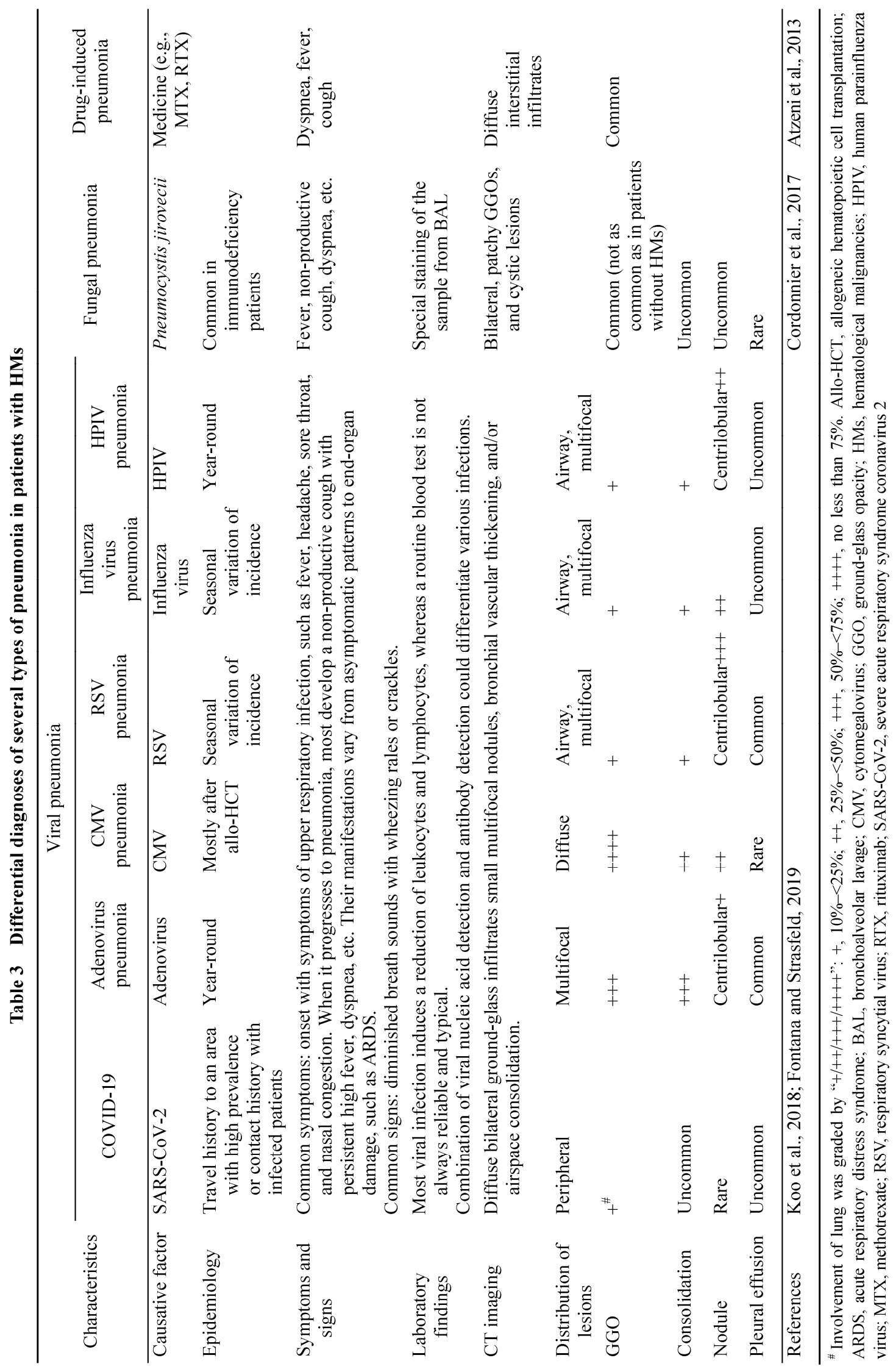


Table 4 Principal causative factors of fever in patients with hematological cancers

\begin{tabular}{ll}
\hline \multicolumn{1}{c}{ Causative factor } & \multicolumn{1}{c}{ Example } \\
\hline Infectious fever & Viral infections, including SARS-CoV-2, CMV, and RSV \\
& Fungal infections \\
& Bacterial infections \\
& Others, such as mycoplasma \\
Treatment-associated fever & Chemotherapeutics, such as high-dose MTX, L-ASP, and Ara-C \\
& aGVHD after HSCT \\
& CRS induced by CAR-T therapy \\
& Others \\
Oncological fever & NHL: body temperature $>38^{\circ} \mathrm{C}$ accompanied by weight loss or (and) night sweats \\
& HL: patients could present with unknown persistent fever; $1 / 6$ patients could develop Pel \\
& Ebstein fever \\
& Others \\
\hline
\end{tabular}

aGVHD, acute graft versus host reaction; Ara-C, cytarabine; CAR-T, chimeric antigen receptor T cell; CMV, cytomegalovirus; CRS, cytokine release syndrome; HL, Hodgkin lymphoma; HSCT, hematopoietic stem cell transplantation; L-ASP, L-asparaginase; MTX, methotrexate; NHL, non-Hodgkin lymphoma; RSV, respiratory syncytial virus; SARS-CoV-2, severe acute respiratory syndrome coronavirus 2

et al., 2020). Moreover, in acute promyelocytic leukemia (APL), petechia on the skin, gingival hemorrhaging, and other familiar manifestations of coagulation dysfunction might disguise COVID-19-induced coagulation abnormalities (Wang YD et al., 2020).

Governments' restrictive measures, public anxiety, and a shift in the primary focus of medical staff to SARS-CoV-2 infection amid the pandemic might lead to underdiagnosis of symptoms in HM patients, deferral of hematological laboratory and radiological tests, and postponement of other hematological exams. Most acute leukemias deteriorate rapidly with severe complications, making prompt diagnosis and treatment crucial. Therefore, telephone calls, telemedicine, or digital platforms should be used to screen for suspicious hematological symptoms (Molica et al., 2020). After a referral to a hospital, a comprehensive evaluation of SARS-CoV-2 and hematological disease should be performed simultaneously.

\section{General management strategies for patients with HMs during the COVID-19 pandemic}

The outbreak of COVID-19 has not only had a massive impact on patients with HMs, but also posed tremendous challenges for medical institutions and medical staff. Routine medical procedures and standards for the diagnosis, treatment, follow-up, and prevention of nosocomial infections need to be adjusted to account for COVID-19.

\subsection{Considerations for hospital admission procedures}

Patients with HMs are advised to follow different hospital admission procedures in view of the prevalence of COVID-19 in different areas of a hospital (Fig. 2). On admission, patients with HMs should be classified according to the risk stratification system for COVID-19 (Table 2). Those patients with a history of COVID-19 exposure or suspicious symptoms should be further investigated. Detailed contact history with exact locations, time, and individuals should be tracked and recorded. Also, blood tests, biochemical analysis, viral nucleic acid detection, viral antibody detection, and chest CT imaging are strongly recommended, to aid in decision-making regarding subsequent diagnostic processes and cancer regimens.

Furthermore, each medical team should carefully weigh the advantages and disadvantages of each inclusion for clinical trials. Clinical trials allow access to off-label drugs or combinations that can be highly beneficial but are otherwise unavailable (Malard and Mohty, 2020). Additionally, routine SARS-CoV-2 testing is also applicable in clinical trials before inclusion.

For highly suspected or confirmed COVID-19 cases, HM patients should be transferred to assigned hospitals for further treatment and isolation. Moreover, a multidisciplinary team (MDT) involving hematologists, infectious disease experts, and other related specialists is necessary to discuss and tailor individualized treatment plans. Throughout the entire medical process, medical staff should be well-protected with full personal protective equipment. 


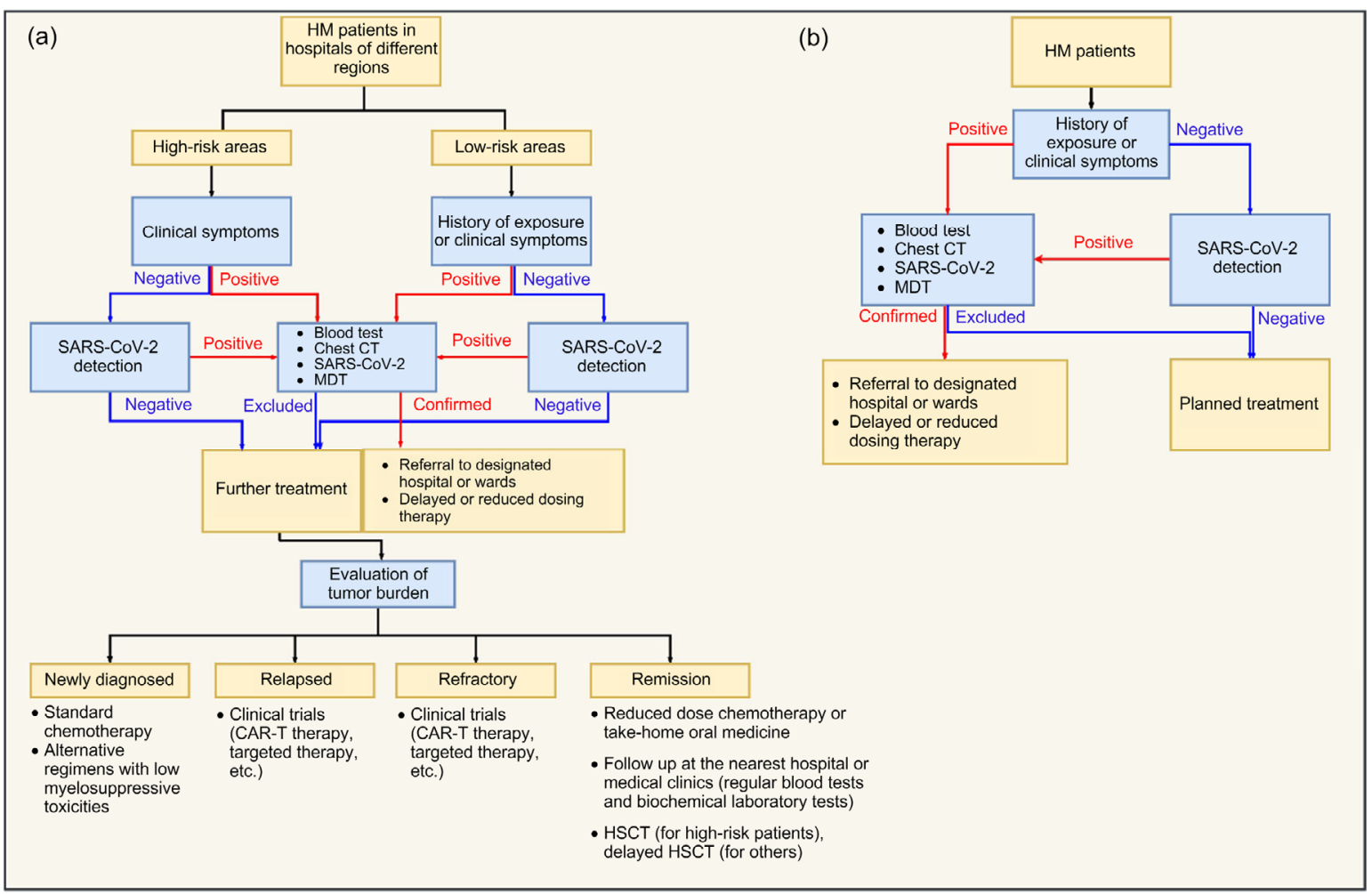

Fig. 2 Flow diagram of hospital admission procedures for HM patients during the COVID-19 pandemic (a) Admission procedures in areas with a high prevalence of COVID-19; (b) Admission procedures in areas with a low prevalence of COVID-19. CAR-T, chimeric antigen receptor T cell; COVID-19, coronavirus disease 2019; CT, computed tomography; HM, hematological malignancy; HSCT, hematopoietic stem cell transplantation; MDT, multidisciplinary team; SARS-CoV-2, severe acute respiratory syndrome coronavirus 2

\subsection{Considerations for hematological therapeutic regimens}

Current options for the treatment of HMs include chemotherapy, immunotherapy, targeted therapy, hematopoietic stem cell transplantation (HSCT), radiotherapy, and cell-based therapy. All of these options would cause detrimental effects on hemopoietic functions, to some extent. Therefore, treatment needs to be adjusted during the COVID-19 outbreak.

\subsubsection{Chemotherapy}

High-dose chemotherapy would severely impair the immune system via non-selective anti-cancer activity. Then, overcoming the sequelae of chemotherapy typically requires extensive medical equipment, medicine, or blood products. However, most medical equipment has been mobilized to emergency departments or COVID-19 wards during this critical period. Therefore, it is necessary to adjust conventional chemotherapy regimens for patients with HMs. The core ideas for converted regimens are as follows: (1) safe and effective oral chemotherapeutic drugs are preferable to reduce the duration of hospitalization; (2) therapeutic regimens should be simplified, with less frequent visits and shorter duration; (3) for patients maintaining remission, the dose of chemotherapy or the frequency of follow-up visits could be reduced; and (4) non-urgent chemotherapy or medical procedures should be deferred.

For newly diagnosed patients with a high tumor burden or multiple high-risk genetic aberrations, the risks and benefits should be carefully weighed because underdosing might not kill the malignant cells efficiently and may induce tolerance to therapy. In Tables $5-7$, we briefly summarize the considerations for treatment regimens of common hematological cancers during the COVID-19 pandemic based on recommendations from the American Society of Hematology (ASH), the European Hematology Association (EHA), and other published guidelines. Before the administration of myelosuppressive treatment, it is vital to rule out COVID-19 infection. 
Table 5 Considerations for treatment of leukemia during the COVID-19 pandemic

\begin{tabular}{|c|c|c|c|c|}
\hline Leukemia & Induction treatment & $\begin{array}{l}\text { Consolidation and } \\
\text { maintenance therapy }\end{array}$ & $\mathrm{R} / \mathrm{R}$ patient & Reference \\
\hline \multicolumn{5}{|c|}{ Acute leukemia } \\
\hline ALL & $\begin{array}{l}\text { Ph-positive: } \\
\text { 1. TKI+minimal corticosteroid } \\
\text { exposure } \\
\text { 2. TKI+low-dose chemotherapy }\end{array}$ & $\begin{array}{l}\text { Ph-positive: } \\
\text { 1. Consolidation therapy is } \\
\text { not suggested for CR } \\
\text { patients } \\
\text { 2. TKI+corticosteroids (for } \\
\text { maintenance therapy) }\end{array}$ & $\begin{array}{l}\text { B-ALL: } \\
\text { 1. Inotuzumab } \\
\text { 2. Blinatumomab or } \\
\text { CD22 CAR-T (with } \\
\text { enough medical } \\
\text { resources) }\end{array}$ & $\begin{array}{l}\text { Gruber et al., } \\
\text { 2009; Gavillet } \\
\text { et al., 2020; } \\
\text { Stock et al., } \\
2020\end{array}$ \\
\hline ALL & $\begin{array}{l}\text { Ph-negative: } \\
\text { 1. Standard chemotherapy } \\
\text { 2. Reduced dose for patients } \\
\text { with high risk of complications } \\
\text { 3. Minimized corticosteroids to } \\
\text { relieve symptoms } \\
\text { 4. G-CSF to facilitate the } \\
\text { recovery of leukocyte count }\end{array}$ & $\begin{array}{l}\text { Ph-negative: } \\
\text { 1. Consolidation therapy is } \\
\text { not suggested for CR } \\
\text { patients } \\
\text { 2. Allo-HSCT } \\
\text { 3. Vincristine+prednisone+ } \\
\text { 6-MP+MTX (for } \\
\text { maintenance therapy) }\end{array}$ & $\begin{array}{l}\text { T-ALL: } \\
\text { 1. Standard } \\
\text { nelarabine-based } \\
\text { regimens } \\
\text { 2. Salvage chemotherapy } \\
\text { and targeted therapies } \\
\text { when necessary }\end{array}$ & $\begin{array}{l}\text { Gavillet et al., } \\
\text { 2020; NCCN, } \\
\text { 2020; Stock } \\
\text { et al., } 2020\end{array}$ \\
\hline AML & $\begin{array}{l}\text { APL: } \\
\text { 1. Targeted oral drugs (e.g., } \\
\text { ATO+ATRA), for low-risk } \\
\text { patients; for high-risk pa- } \\
\text { tients, regimens should in- } \\
\text { clude a cytotoxic agent } \\
\text { 2. Dexamethasone (to prevent } \\
\text { DS) }\end{array}$ & $\begin{array}{l}\text { APL: } \\
\text { ATO to achieve a low } \\
\text { relapse rate }\end{array}$ & $\begin{array}{l}\text { 1. Salvage intensive } \\
\text { re-induction } \\
\text { 2. HSCT, aggressive } \\
\text { chemotherapy or } \\
\text { targeted therapies }\end{array}$ & $\begin{array}{l}\text { Raza et al., 2020; } \\
\text { Tallman et al., } \\
2020\end{array}$ \\
\hline AML & $\begin{array}{l}\text { Non-APL: } \\
\text { 1. "7+3" regimen } \\
\text { 2. Preventive antimicrobial } \\
\text { drugs+G-CSF } \\
\text { 3. Targeted drugs with reduced } \\
\text { doses } \\
\text { 4. Adjusted blood supply } \\
\text { standards }\end{array}$ & $\begin{array}{l}\text { Non-APL: } \\
\text { 1. High-dose cytarabine+ } \\
\text { reduced-dose cytarabine } \\
\text { (decreased to three cycles) } \\
\text { 2. Oral BCL-2 inhibitor } \\
\text { alone or combined with } \\
\text { 5-azacitidine }\end{array}$ & & $\begin{array}{l}\text { Gavillet et al., } \\
\text { 2020; NCCN, } \\
\text { 2020; Tallman } \\
\text { et al., } 2020\end{array}$ \\
\hline \multicolumn{5}{|c|}{ Chronic leukemia } \\
\hline CLL & \multicolumn{3}{|c|}{$\begin{array}{l}\text { 1. First-line treatment like ibrutinib could be continued with less frequent follow-ups } \\
\text { 2. Monoclonal anti-CD } 20 \text { antibodies and IVIG } \\
\text { 3. Avoid the combination of targeted therapy } \\
\text { 4. Venetoclax should be cautiously prescribed if necessary, owing to the need for fre- } \\
\text { quent hemogram monitoring }\end{array}$} & $\begin{array}{l}\text { Shadman et al., } \\
\quad 2020\end{array}$ \\
\hline CML & \multicolumn{3}{|c|}{$\begin{array}{l}\text { 1. Newly diagnosed: first-line treatment of TKI with the close monitoring of hemograms } \\
\text { 2. Accelerated phase: continuing TKI if clinical response is positive } \\
\text { 3. For others, dose interruptions or reductions could be considered }\end{array}$} & Mauro et al., 2020 \\
\hline
\end{tabular}

ALL, acute lymphoblastic leukemia; Allo-HSCT, allogeneic hematopoietic stem cell transplantation; AML, acute myeloid leukemia; APL, acute promyelocytic leukemia; ATRA, all-trans retinoic acid; ATO, arsenic trioxide; B-ALL, B cell-ALL; CAR-T, chimeric antigen receptor T cell; CLL, chronic lymphoblastic leukemia; CML, chronic myeloid leukemia; COVID-19, coronavirus disease 2019; CR, complete remission; DS, differentiation syndrome; G-CSF, granulocyte-colony stimulating factor; IVIG, intravenous immunoglobulin; 6-MP, 6-mercapto-purine; MTX, methotrexate; Ph, Philadelphia chromosome; R/R, relapsed or refractory; T-ALL, T-cell ALL; TKI, tyrosine kinase inhibitors

\subsubsection{Immunotherapy}

Unlike chemotherapy, novel therapies, like monoclonal antibodies, bispecific T-cell receptor-engaging antibodies, and chimeric antigen receptor T cell (CAR-T) therapies, aim to precisely eradicate malignant cells by recognizing surface antigens on tumor cells in relapsed or refractory HMs. However, for CAR-T therapy, long-term B-cell aplasia would increase susceptibility to infections. Also, cytokine release syndrome, the most common toxicity associated with CAR-T therapy, would promote cytokine storms with COVID-19. Fortunately, Bachanova et al. (2020) proposed appropriate strategies and useful guidelines for CAR-T therapy during the COVID-19 pandemic. 
Table 6 Considerations for treatment of lymphoma during the COVID-19 pandemic

\begin{tabular}{|c|c|c|c|c|}
\hline Lymphoma & Induction treatment & $\begin{array}{l}\text { Consolidation and } \\
\text { maintenance therapy }\end{array}$ & $\mathrm{R} / \mathrm{R}$ patient & Reference \\
\hline HL & $\begin{array}{l}\text { Early stage: } \\
\quad \text { Four cycles of ABVD with } \\
\text { an interim of PET-CT } \\
\quad \text { (favorable disease) } \\
\text { Advanced stage: } \\
\text { 1. ABVD+PET/CT } \\
\text { 2. AAVD+G-CSF }\end{array}$ & $\begin{array}{l}\text { Conventional HL } \\
\text { regimens }+ \\
\text { prophylactic antibiotics }\end{array}$ & $\begin{array}{l}\text { 1. Second-line regimens } \\
\text { (e.g., gemcitabine-based } \\
\text { regimens) } \\
\text { 2. Brentuximab vedotin or } \\
\text { PD1 antibodies }\end{array}$ & $\begin{array}{l}\text { Advani et al., } \\
\text { 2020b; } \\
\text { ESMO, 2020b }\end{array}$ \\
\hline $\begin{array}{l}\text { NHL (mainly } \\
\text { focused on } \\
\text { DLBCL) }\end{array}$ & $\begin{array}{l}\text { High-risk: } \\
\text { 1. CHOP-21 regimens } \\
\text { 2. G-CSF to minimize } \\
\text { neutropenia } \\
\text { Medium-risk: } \\
\text { 1. Non-curative treatment } \\
\text { could be delayed } \\
\text { 2. Avoid T-cell suppressive } \\
\text { agents (e.g., bendamustine) }\end{array}$ & $\begin{array}{l}\text { High-risk: } \\
\text { Lenalidomide+RTX } \\
\text { (R2) or lenalidomide+ } \\
\text { corticosteroids } \\
\text { Others: } \\
\text { 6-MP+MTX }\end{array}$ & $\begin{array}{l}\text { 1. High-dose chemotherapy+ } \\
\text { ASCT } \\
\text { 2. Second-line chemotherapy } \\
\text { 3. Lenalidomide-based } \\
\text { therapy } \\
\text { 4. Polatuzamab+ } \\
\text { bendamustine } \\
\text { 5. CAR-T cell therapy }\end{array}$ & $\begin{array}{l}\text { Advani et al., } \\
\text { 2020a; } \\
\text { ESMO, 2020a }\end{array}$ \\
\hline
\end{tabular}

AAVD, brentuximab vedotin, doxorubicin, vinblastine, and dacarbazine; ABVD, doxorubicin, bleomycin, vinblastine, and dacarbazine; ASCT, autologous stem cell transplantation; CAR-T, chimeric antigen receptor T cell; CHOP-21, three-weekly cyclophosphamide, doxorubicin, vincristine, and prednisolone; COVID-19, coronavirus disease 2019; DLBCL, diffuse large B-cell lymphoma; G-CSF, granulocyte-colony stimulating factor; HL, Hodgkin lymphoma; 6-MP, 6-mercapto-purine; MTX, methotrexate; NHL, non-Hodgkin lymphoma; PD1, programmed cell death protein 1 ; PET/CT, positron emission tomography/computed tomography; R/R, relapsed or refractory; RTX, rituximab

Table 7 Considerations for treatment of multiple myeloma during the COVID-19 pandemic

\begin{tabular}{|c|c|c|c|c|}
\hline $\begin{array}{l}\text { Multiple } \\
\text { myeloma }\end{array}$ & Induction treatment & $\begin{array}{c}\text { Consolidation and } \\
\text { maintenance therapy }\end{array}$ & $\mathrm{R} / \mathrm{R}$ patient & Reference \\
\hline Standard-risk & $\begin{array}{l}\text { 1. Lenalidomide, bortezomib, and } \\
\text { dexamethasone (RVd regimen) } \\
\text { 2. Oral ixazomib, lenalidomide, and } \\
\text { dexamethasone (IRd regimen; } 28 \text {-d cycle) } \\
\text { 3. CRd regimen; 28-d cycle } \\
\text { 4. DRd regimen for elderly patients } \\
\text { 5. CyBorD regiment: the only approved } \\
\text { initial therapy } \\
\text { 6. Clinic visits at an interval of } 4 \text { weeks } \\
\text { 7. Consider administering additional cycles } \\
\text { of induction, and delaying transplant } \\
\text { until the first relapse }\end{array}$ & $\begin{array}{l}\text { 1. Reduced dose of } \\
\text { dexamethasone with } \\
\text { follow-up for those } \\
\text { with good responses } \\
\text { after } 3 \text { - } 4 \text { cycles } \\
\text { 2. Bortezomib on a } \\
\text { weekly basis after } \\
6-8 \text { cycles } \\
\text { 3. If remission after } \\
\text { 10-12 cycles, le- } \\
\text { nalidomide }\end{array}$ & $\begin{array}{l}\text { 1. Salvage ASCT } \\
\text { (for aggressive } \\
\text { relapse or } \\
\text { secondary PCL) } \\
\text { 2. Daratumumab- } \\
\text { based treatment }\end{array}$ & $\begin{array}{l}\text { A1 Saleh et al., } \\
\text { 2020; Malard } \\
\text { and Mohty, } \\
\text { 2020; } \\
\text { Rajkumar } \\
\text { et al., } 2020\end{array}$ \\
\hline High-risk & $\begin{array}{l}\text { 1. Twenty-eight-day cycle of carfilzomib, } \\
\text { lenalidomide, and dexamethasone (KRd } \\
\text { regimen) } \\
\text { 2. High-dose melphalan and ASCT as } \\
\text { first-line treatments } \\
\text { 3. Weekly outpatient clinic visits }\end{array}$ & $\begin{array}{l}\text { 1. RVd or Rd regimens } \\
\text { 2. Acquiring ASCT } \\
\text { post-pandemic }\end{array}$ & & $\begin{array}{l}\text { Al Saleh et al., } \\
\text { 2020; } \\
\text { Rajkumar } \\
\text { et al., } 2020\end{array}$ \\
\hline
\end{tabular}

\subsubsection{Hematopoietic stem cell transplantation}

HSCT is an established and indispensable therapy for helping advanced-stage patients to achieve longterm survival (Gruber et al., 2009). Before its administration, patients should be treated with high-dose chemotherapy, inducing a relatively long period of pancytopenia and increasing susceptibility to various infections. However, its implementation is challenging during the COVID-19 pandemic. Therefore, strict measures, such as the use of rooms with laminar flow hoods or positive pressure isolation wards, should be adopted for this cohort. Furthermore, non-urgent transplantation procedures for patients with stable 
diseases could be deferred. Moreover, COVID-19 screening should be conducted for both donors and recipients (Ljungman et al., 2020). To reduce the falsenegative rate, the combination of SARS-CoV-2 nucleic acid and antibody tests should be performed at least twice at an interval of at least $24 \mathrm{~h}$ prior to HSCT.

To minimize the influence of unpredictable factors, the cryopreservation of stem cells before the conditioning regimen and the preparation of a back-up donor is recommended by the European Society for Blood and Marrow Transplantation (Ljungman et al., 2020). If a transplant candidate is diagnosed with COVID-19, HSCT should be delayed for at least three months. For individuals who were in close contact with patients with COVID-19, HSCT should not be performed for at least 14 to $21 \mathrm{~d}$ (Ljungman et al., 2020).

\subsubsection{Recommendations for regimen adjustments}

\subsubsection{Acute leukemia}

In acute myeloid leukemia (AML), the regimens differ remarkably between APL and non-APL. For non-APL, following a negative COVID-19 test, intensive induction chemotherapy is recommended with a curative intent (Raza et al., 2020). Lower-intensity therapies such as a hypomethylating agent with venetoclax can be administered to people as outpatients to reduce exposure (DiNardo et al., 2019). Moreover, the consolidation with high-dose cytarabine should be offered to individuals with negative COVID-19 testing The dose could be lowered (from 3.0 to $1.5 \mathrm{mg} / \mathrm{m}^{2}$ ) to shorten the duration of myelosuppression, and the cycles could be reduced (Mayer et al., 1994; Burnett et al., 2013; Brissot et al., 2020). For APL, the regimen of "oral all-trans retinoic acid (ATRA) and arsenic trioxide" is more desirable for low-risk individuals, owing to the reduced duration of myelosuppression (Zhu and Huang, 2014). High-risk patients must still receive a regimen that includes a cytotoxic agent. In ALL, glucocorticoids should be prescribed in a recommended dose, given the paucity of information on their potential adverse role in SARSCoV-2 infections. Meanwhile, bacterial and fungal infections and the inherent risk of thrombotic complications should be prevented in advance (Brissot et al., 2020).

\subsubsection{Chronic leukemia}

Among patients with CLL, a "watch and wait" policy has been widely adopted during this epidemic. Notably, given the dismal outcome of infection, self- isolating should be strictly performed to limit a patient's exposure to viral infection (Paneesha et al., 2020). Because of the potential of Bruton tyrosine kinase (BTK) inhibitors to disturb pulmonary inflammation and immune response in COVID-19, they could be reserved for the treatment of CLL and other indications, such as mantle cell lymphoma and Waldenstrom macroglobulinemia (Scarfò et al., 2020; Treon et al., 2020).

As for CML, the absolute risk of contracting a severe SARS-CoV-2 infection was lower than $1 \%$ (Ector et al., 2020; Li et al., 2020). Leukemia-associated factors, including no complete hematologic response and subjects in advanced phase CML, were found to be the risk factors of infection, whereas the use of TKI was not ( $\mathrm{Li}$ et al., 2020). Therefore, it was safe to continue their TKI.

\subsubsection{Lymphoma}

Diffuse large B-cell lymphoma is the most common aggressive non-Hodgkin lymphoma. For newly diagnosed patients, R-CHOP (rituximab, cyclophosphamide, doxorubicin, vincristine, and prednisone), as the standard regimen, is recommended to be performed immediately. Moreover, the cycle of R-CHOP could be reduced to four cycles if the positron emission tomography (PET) is negative at the end of treatment (di Ciaccio et al., 2020).

\subsubsection{Multiple myeloma}

As for MM, high-dose melphalan and autologous HSCT (ASCT) remain the standard care. At the same time, hemopoietic recovery takes a long time after this therapy. Therefore, it was recommended to perform induction regimens of up to six cycles to postpone the ASCT. In the standard-risk group, transplant could be delayed until the first relapse because no significant effect on overall survival rate has been observed in this adjusted regimen. In the high-risk group, ASCT should still be regarded as first-line therapy, and SARS-CoV-2 screening should be highlighted throughout the therapy (Malard and Mohty, 2020). Referring to the current guidelines, Table 7 summarizes induction, consolidation, and maintenance therapies, and regimens for relapsed or refractory MM.

\subsection{Considerations for follow-up plans}

Unfortunately, routine follow-up has been strongly influenced by traffic restrictions and travel bans during the COVID-19 pandemic. In this context, patients 
should seek medical care at the nearest hospital to ensure treatment in the shortest time and minimize opportunities for exposure to COVID-19. Furthermore, telemedicine could be introduced to enable communication between patients and doctors. Video conferencing platforms, such as Zoom, WeChat, and Skype, could be used for collaborations among different medical institutions. If infection or disease progression is suspected, patients could search for timely medical assistance.

Once the travel bans are lifted, pre-planned treatment and follow-up strategies could be resumed. However, the screening and testing of suspected COVID-19 cases should be continued. The precautions of proper handwashing methods, masking, social distancing, and good personal hygiene should be disseminated and strictly practiced among vulnerable cohorts. Above all, the most effective method to prevent COVID-19 transmission is still likely to be vaccination, once it becomes available.

\section{Comprehensive intervention strategies for patients with COVID-19 and preexisting HMs}

The coexistence of HMs and COVID-19 infection is rather complicated and challenging for medical experts. During comprehensive care, in severely infected cases, COVID-19 should be prioritized over HMs. Generally, patients with COVID-19 and HMs should be isolated, and comprehensive treatment strategies should be designed according to the severity of the disease. The core interventions include the clearance of viremia, relieving cytokine storms, and improving organ function.

Aiming to target the direct action of the virus on multiple organs, antivirals (e.g., lopinavir/ritonavir, remdesivir) and antibodies (e.g., convalescent plasma) are under evaluation for their safety and feasibility for managing COVID-19 (Wiersinga et al., 2020). Emerging evidence shows the favorable effect of convalescent plasma infusion on improving symptoms and biomedical indices, and proves that early administration with convalescent plasma is preferable before seroconversion for SARS-CoV-2. Convalescent plasma also shows an acceptable safety profile (Psaltopoulou et al., 2020). Most other medications did not show significant benefits for patients (Wiersinga et al., 2020).
A cytokine storm initiated by SARS-CoV-2 would induce a series of adverse effects, such as a hypercoagulable inflammatory state, increasing the risk of secondary infections, and impairing humoral immunity (Chauhan et al., 2020; Jamilloux et al., 2020). Therefore, targeted immunomodulatory agents (e.g., tocilizumab, ruxolitinib) and anti-inflammatory agents (e.g., dexamethasone) have been used to curb cytokine storms. Thromboprophylaxis is necessary among COVID-19 patients. Low-molecular weight heparins are the firstline choice, and other antithrombotic treatments such as antithrombin could be integrated (Terpos et al., 2020a).

The monitoring of blood oxygen saturation and oxygen therapy should be appropriately and promptly adopted as hypoxemia, or cytokine release syndrome would contribute to the development of shock, tissue perfusion disorders, and even multiple organ failure. Oxygen saturation should be maintained at $93 \%-96 \%$ for patients without chronic pulmonary disease and at $88 \%-92 \%$ for patients with chronic type II respiratory failure.

Artificial liver support systems and blood purification efficiently reduce the incidence of shock, hypoxemia, and respiratory distress syndrome (Liang et al., 2020). For patients with HMs and COVID-19, the prophylactic use of antibiotics is necessary (quinolones, second- or third-generation cephalosporins, and $\beta$-lactamase inhibitor compounds). Alternatives, such as carbapenems, $\beta$-lactamase inhibitor compounds, linezolid, and vancomycin, can be used in critically ill patients.

Supportive treatment and nutritional support are crucial to maintaining the balance of the intracellular environment. A perturbation of the intestinal microecological balance in patients with COVID-19 can result in gastrointestinal symptoms, such as diarrhea, abdominal pain, and even secondary infection. Therefore, patients with severe COVID-19 infection would benefit from regular oral feeding and enteral nutrition.

With the improvement of fever, respiratory symptoms, and radiologic and laboratory results, patients with HMs could be discharged after approval of the MDT. Importantly, two consecutive nucleic acid tests from throat swab specimens should test negative, with a sampling interval of at least $24 \mathrm{~h}$ (Liang et al., 2020). 
After discharge, patients with COVID-19 and HMs must continue two weeks of home quarantine and isolation. Personal hygiene measures, such as handwashing and mask-wearing, should be emphasized. Re-examinations should include liver and kidney functions, blood tests, nucleic acid tests of sputum and stool samples, and a pulmonary function test or lung CT scan, according to the patient's condition. Remote management and telemedicine should be introduced for follow-ups (Balduzzi et al., 2020).

\section{Conclusions}

We have summarized atypical symptoms and features of patients with COVID-19 and HMs based on our broad experience and data, as well as the recently published literature. The prolonged incubation period, complicated laboratory patterns, and confounding radiologic findings might eventually lead to the misdiagnosis of COVID-19 in patients with HMs. Furthermore, we have described additional considerations related to the diagnosis, differential diagnosis, and management of patients with HMs based on our clinical experiences. Amid the COVID-19 pandemic, patients with HM should be managed individually based on the severity and type of disease. Hematological cancer treatments during this critical period should be adjusted on a case-by-case basis. For patients with HMs and confirmed COVID-19, timely supportive treatment, antiviral regimens, oxygen therapy, and prophylactic antibiotics should be administered. An overview of management strategies for patients with HMs during the COVID-19 pandemic is illustrated in Fig. 3.

We have also acknowledged the importance of home-based oral chemotherapy to reduce clinic visits. Moreover, a simplified chemotherapy regimen with higher therapeutic efficacy and lower toxicity for patients with HMs is indispensable. Lastly, hematology wards should be alert and prepared for emergencies and disease outbreaks. For example, procedures for hospital admission, mass screening, quarantine and isolation, and novel treatments for emergency conditions should be well-planned. Strengthening emergency preparedness, immediate responses, and timely recovery are critical to avoid future pandemics.

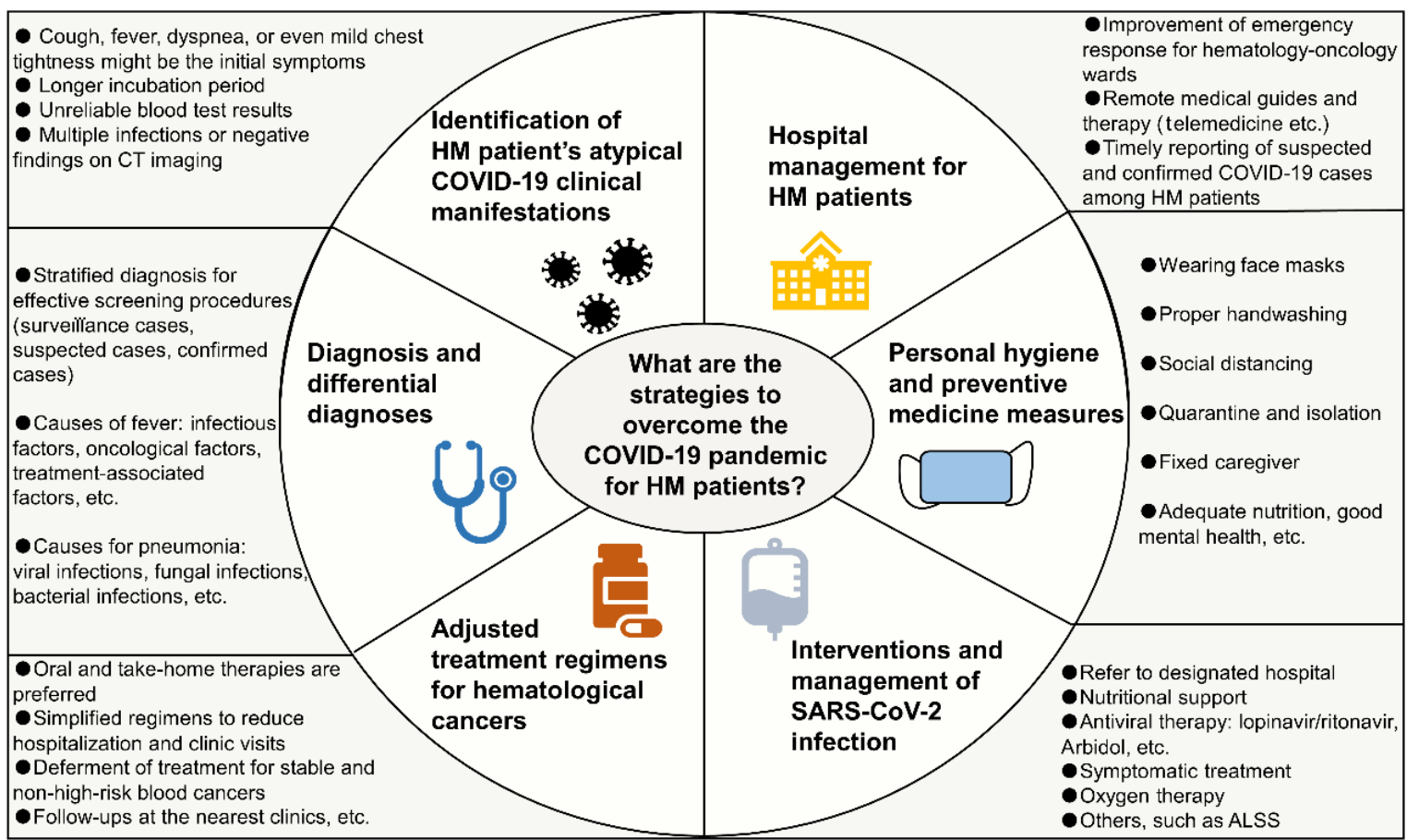

Fig. 3 Overview of management strategies for HM patients during the COVID-19 pandemic ALSS, artificial liver support system; HM, hematological malignancy; COVID-19, coronavirus disease 2019; CT, computed tomography; SARS-CoV-2, severe acute respiratory syndrome coronavirus 2 


\section{Contributors}

He HUANG, Arnon NAGLER, and Yong-xian HU took the lead in writing the manuscript. Lin-qin WANG and Elaine TAN SU YIN wrote and edited the manuscript. Guo-qing WEI participated in shaping the tables and figures. All authors have read and approved the final manuscript and, therefore, have full access to all the data in the study and take responsibility for the integrity and security of the data.

\section{Compliance with ethics guidelines}

He HUANG, Arnon NAGLER, Yong-xian HU, Lin-qin WANG, Elaine TAN SU YIN, and Guo-qing WEI declare that they have no conflict of interest.

This article does not contain any studies with human or animal subjects performed by any of the authors.

\section{References}

Abruzzese E, Luciano L, D'Agostino F, et al., 2020. SARSCoV-2 (COVID-19) and chronic myeloid leukemia (CML): a case report and review of ABL kinase involvement in viral infection. Mediterr J Hematol Infect Dis, 12(1):e2020031. https://doi.org/10.4084/MJHID.2020.031

Advani R, Bartlett N, Gordon L, et al., 2020a. COVID-19 and aggressive lymphoma: frequently asked questions. https://www.hematology.org/covid-19/covid-19-andaggressive-lymphoma [Accessed on Aug. 1, 2020].

Advani R, Bartlett N, Gordon L, et al., 2020b. COVID-19 and Hodgkin lymphoma: frequently asked questions. https:// www.hematology.org/covid-19/covid-19-and-hodgkinlymphoma [Accessed on Aug. 1, 2020].

Ai T, Yang ZL, Hou HY, et al., 2020. Correlation of chest CT and RT-PCR testing for coronavirus disease 2019 (COVID-19) in China: a report of 1014 cases. Radiology, 296(2):E32-E40. https://doi.org/10.1148/radiol.2020200642

Al Saleh AS, Sher T, Gertz MA, 2020. Multiple myeloma in the time of COVID-19. Acta Haematol, 143(5):410-416. https://doi.org/10.1159/000507690

Atzeni F, Boiardi L, Salli S, et al., 2013. Lung involvement and drug-induced lung disease in patients with rheumatoid arthritis. Expert Rev Clin Immunol, 9(7):649-657. https://doi.org/10.1586/1744666X.2013.811173

Bachanova V, Bishop MR, Dahi P, et al., 2020. Chimeric antigen receptor $\mathrm{T}$ cell therapy during the COVID-19 pandemic. Biol Blood Marrow Transplant, 26(7):12391246.

https://doi.org/10.1016/j.bbmt.2020.04.008

Balduzzi A, Brivio E, Rovelli A, et al., 2020. Lessons after the early management of the COVID-19 outbreak in a pediatric transplant and hemato-oncology center embedded within a COVID-19 dedicated hospital in Lombardia, Italy. Estote parati. Bone Marrow Transplant, 55(10):1905. https://doi.org/10.1038/s41409-020-0895-4

Baumann T, Delgado J, Montserrat E, 2020. CLL and COVID-19 at the hospital clinic of Barcelona: an interim report. Leukemia, 34(7):1954-1956. https://doi.org/10.1038/s41375-020-0870-5

Boulware DR, Pullen MF, Bangdiwala AS, et al., 2020. A randomized trial of hydroxychloroquine as postexposure prophylaxis for COVID-19. N Engl J Med, 383(6):517-525. https://doi.org/10.1056/NEJMoa2016638

Brissot E, Labopin M, Baron F, et al., 2020. Management of patients with acute leukemia during the COVID-19 outbreak: practical guidelines from the Acute Leukemia Working Party of the European Society for Blood and Marrow Transplantation. Bone Marrow Transplant, online. https://doi.org/10.1038/s41409-020-0970-x

Burnett AK, Russell NH, Hills RK, et al., 2013. Optimization of chemotherapy for younger patients with acute myeloid leukemia: results of the medical research council AML15 trial. J Clin Oncol, 31(27):3360-3368. https://doi.org/10.1200/JCO.2012.47.4874

Busca A, 2012. Viral infections in patients with hematological malignancies. Leuk Suppl, 1(S2):S24-S25. https://doi.org/10.1038/leusup.2012.15

Byrne CJ, Roberts JA, McWhinney B, et al., 2017. Variability in trough total and unbound teicoplanin concentrations and achievement of therapeutic drug monitoring targets in adult patients with hematological malignancy. Antimicrob Agents Chemother, 61(6):e02466-16. https://doi.org/10.1128/AAC.02466-16

Chauhan AJ, Wiffen LJ, Brown TP, 2020. COVID-19: a collision of complement, coagulation and inflammatory pathways. J Thromb Haemost, 18(9):2110-2117. https://doi.org/10.1111/jth.14981

Chen Z, Xiong H, Li JX, et al., 2020. COVID-19 with postchemotherapy agranulocytosis in childhood acute leukemia: a case report. Chin J Hematol, 41(4):341-343 (in Chinese) https://doi.org/10.3760/cma.j.issn.0253-2727.2020.0004

China National Health Commission, 2020. Chinese Clinical Guidance for COVID-19 pneumonia diagnosis and treatment (7th Edition). http://kjfy.meetingchina.org/msite/ news/show/cn/3337.html?from=singlemessage\&isappins talled $=0$ [Accessed on Mar. 4, 2020].

Cook G, Ashcroft AJ, Pratt G, et al., 2020. Real-world assessment of the clinical impact of symptomatic infection with severe acute respiratory syndrome coronavirus (COVID-19 disease) in patients with multiple myeloma receiving systemic anti-cancer therapy. Br J Haematol, 190(2):e83-e86. https://doi.org/10.1111/bjh.16874

Cordonnier C, Alanio A, Cesaro S, et al., 2017. Pneumocystis jirovecii pneumonia: still a concern in patients with haematological malignancies and stem cell transplant recipients-authors' response. J Antimicrob Chemother, 72(4):1266-1268. https://doi.org/10.1093/jac/dkw580

di Ciaccio P, McCaughan G, Trotman J, et al., 2020. Australian and New Zealand consensus statement on the management of lymphoma, chronic lymphocytic leukaemia and myeloma during the COVID-19 pandemic. Intern Med J, 
50(6):667-679.

https://doi.org/10.1111/imj.14859

DiNardo CD, Pratz K, Pullarkat V, et al., 2019. Venetoclax combined with decitabine or azacitidine in treatmentnaive, elderly patients with acute myeloid leukemia. Blood, 133(1):7-17.

https://doi.org/10.1182/blood-2018-08-868752

Ector GICG, Huijskens EGW, Blijlevens NMA, et al., 2020. Prevalence of COVID-19 diagnosis in Dutch CML patients during the 2020 SARS-CoV2 pandemic. A prospective cohort study. Leukemia, 34(9):2533-2535. https://doi.org/10.1038/s41375-020-0964-0

ESMO (European Society for Medical Oncology), 2020a. ESMO management and treatment adapted recommendations in the COVID-19 era: diffuse large B-cell lymphoma, mantle cell lymphoma and aggressive T-cell lymphomas. https://www.esmo.org/guidelines/cancer-patientmanagement-during-the-covid-19-pandemic/haematologicalmalignancies-dlbcl-mcl-and-aggressive-t-cell-lymphomain-the-second-phase-of-the-covid-19-pandemic-esmo-eha [Accessed on Aug. 1, 2020].

ESMO (European Society for Medical Oncology), 2020b. ESMO management and treatment adapted recommendations in the COVID-19 era: hodgkin lymphoma. https:// www.esmo.org/guidelines/cancer-patient-managementduring-the-covid-19-pandemic/haematological-malignancieshodgkin-lymphoma-in-the-second-phase-of-the-covid-19pandemic-esmo-eha [Accessed on Aug. 1, 2020].

Farmer I, Okikiolu J, Steel M, et al., 2020. Acute promyelocytic leukaemia lying under the mask of COVID-19a diagnostic and therapeutic conundrum. Br J Haematol, 190(4):e248-e250.

https://doi.org/10.1111/bjh.16864

Foà R, Bonifacio M, Chiaretti S, et al., 2020. Philadelphiapositive acute lymphoblastic leukaemia (ALL) in Italy during the COVID-19 pandemic: a Campus ALL study. Br J Haematol, 190(1):e3-e5. https://doi.org/10.1111/bjh.16758

Fontana L, Strasfeld L, 2019. Respiratory virus infections of the stem cell transplant recipient and the hematologic malignancy patient. Infect Dis Clin North Am, 33(2):523544. https://doi.org/10.1016/j.idc.2019.02.004

Freeman CL, Sehn LH, 2018. A tale of two antibodies: obinutuzumab versus rituximab. Br J Haematol, 182(1):29-45. https://doi.org/10.1111/bjh.15232

Gavillet M, Klappert JC, Spertini O, et al., 2020. Acute leukemia in the time of COVID-19. Leuk Res, 92:106353. https://doi.org/10.1016/j.leukres.2020.106353

Gavriatopoulou M, Korompoki E, Fotiou D, et al., 2020. Organspecific manifestations of COVID-19 infection. Clin Exp Med, 20(4):493-506. https://doi.org/10.1007/s10238-020-00648-x

Gruber F, Mustjoki S, Porkka K, 2009. Impact of tyrosine kinase inhibitors on patient outcomes in Philadelphia chromosome-positive acute lymphoblastic leukaemia. $\mathrm{Br}$
J Haematol, 145(5):581-597.

https://doi.org/10.1111/j.1365-2141.2009.07666.x

Gu JY, Han B, Wang J, 2020. COVID-19: gastrointestinal manifestations and potential fecal-oral transmission. Gastroenterology, 158(6):1518-1519.

https://doi.org/10.1053/j.gastro.2020.02.054

Guan WJ, Ni ZY, Hu Y, et al., 2020. Clinical characteristics of coronavirus disease 2019 in China. N Engl J Med, 382(18):1708-1720. https://doi.org/10.1056/NEJMoa2002032

Hamming I, Timens W, Bulthuis MLC, et al., 2004. Tissue distribution of ACE2 protein, the functional receptor for SARS coronavirus. A first step in understanding SARS pathogenesis. J Pathol, 203(2):631-637. https://doi.org/10.1002/path.1570

Han QM, Lin QQ, Jin SH, et al., 2020. Coronavirus 2019-nCoV: a brief perspective from the front line. $J$ Infect, 80(4):373377. https://doi.org/10.1016/j.jinf.2020.02.010

He WJ, Chen L, Chen L, et al., 2020. COVID-19 in persons with haematological cancers. Leukemia, 34(6):1637-1645. https://doi.org/10.1038/s41375-020-0836-7

Jamilloux Y, Henry T, Belot A, et al., 2020. Should we stimulate or suppress immune responses in COVID-19? Cytokine and anti-cytokine interventions. Autoimmun Rev, 19(7): 102567. https://doi.org/10.1016/j.autrev.2020.102567

Jin XH, Zheng KI, Pan KH, et al., 2020. COVID-19 in a patient with chronic lymphocytic leukaemia. Lancet Haematol, 7(4):E351-E352. https://doi.org/10.1016/S2352-3026(20)30074-0

Jones DL, Baluja MQ, Graham DW, et al., 2020. Shedding of SARS-CoV-2 in feces and urine and its potential role in person-to-person transmission and the environment-based spread of COVID-19. Sci Total Environ, 749:141364. https://doi.org/10.1016/j.scitotenv.2020.141364

June CH, Sadelain M, 2018. Chimeric antigen receptor therapy. N Engl J Med, 379(1):64-73. https://doi.org/10.1056/NEJMra1706169

Koo HJ, Lim S, Choe J, et al., 2018. Radiographic and CT features of viral pneumonia. Radiographics, 38(3):719-739. https://doi.org/10.1148/rg.2018170048

Lagunas-Rangel FA, 2020. Neutrophil-to-lymphocyte ratio and lymphocyte-to-C-reactive protein ratio in patients with severe coronavirus disease 2019 (COVID-19): a meta-analysis. J Med Virol, 92(10):1733-1734. https://doi.org/10.1002/jmv.25819

Li T, Yang Z, Jiang S, et al., 2018. Melatonin: does it have utility in the treatment of haematological neoplasms? Br J Pharmacol, 175(16):3251-3262. https://doi.org/10.1111/bph.13966

Li WM, Wang DY, Guo JM, et al., 2020. COVID-19 in persons with chronic myeloid leukaemia. Leukemia, 34(7): 1799-1804. https://doi.org/10.1038/s41375-020-0853-6

Liang T, Cai HL, Chen Y, et al., 2020. Handbook of COVID-19 
Prevention and Treatment. https://gmcc.alibabadoctor.com/ prevention-manual [Accessed on Mar. 18, 2020].

Liang WH, Guan WJ, Chen RC, et al., 2020. Cancer patients in SARS-CoV-2 infection: a nationwide analysis in China. Lancet Oncol, 21(3):335-337.

https://doi.org/10.1016/S1470-2045(20)30096-6

Ljungman P, Mikulska M, de la Camara R, et al., 2020. The challenge of COVID-19 and hematopoietic cell transplantation; EBMT recommendations for management of hematopoietic cell transplant recipients, their donors, and patients undergoing CAR T-cell therapy. Bone Marrow Transplant, 55:2071-2076. https://doi.org/10.1038/s41409-020-0919-0

Malard F, Mohty M, 2020. Management of patients with multiple myeloma during the COVID-19 pandemic. Lancet Haematol, 7(6):E435-E437.

https://doi.org/10.1016/S2352-3026(20)30124-1

Malard F, Genthon A, Brissot E, et al., 2020. COVID-19 outcomes in patients with hematologic disease. Bone Marrow Transplant, 55(11):2180-2184. https://doi.org/10.1038/s41409-020-0931-4

Mao L, Jin HJ, Wang MD, et al., 2020. Neurologic manifestations of hospitalized patients with coronavirus disease 2019 in Wuhan, China. JAMA Neurol, 77(6):683-690. https://doi.org/10.1001/jamaneurol.2020.1127

Mauro M, Druker B, Radich J, et al., 2020. COVID-19 and CML: frequently asked questions. https://www.hematology. org/covid-19/covid-19-and-cml [Accessed on Aug. 1, 2020].

Mayer RJ, Davis RB, Schiffer CA, et al., 1994. Intensive postremission chemotherapy in adults with acute myeloid leukemia. N Engl J Med, 331(14):896-903. https://doi.org/10.1056/NEJM199410063311402

Mehta P, McAuley DF, Brown M, et al., 2020. COVID-19: consider cytokine storm syndromes and immunosuppression. Lancet, 395(10229):1033-1034. https://doi.org/10.1016/S0140-6736(20)30628-0

Molica M, Mazzone C, Cordone I, et al., 2020. SARS-CoV-2 infection anxieties and general population restrictions delay diagnosis and treatment of acute haematological malignancies. Br J Haematol, 190(1):e5-e8. https://doi.org/10.1111/bjh.16785

NCCN (National Comprehensive Cancer Network), 2020. NCCN Guidelines ${ }^{\circledR}$. https://www.nccn.org/professionals/ physician_gls/default.aspx [Accessed on July 1, 2020].

O'Kelly B, McGettrick P, Angelov D, et al., 2020. Outcome of a patient with refractory Hodgkin lymphoma on pembrolizumab, infected with SARS-CoV-2. Br J Haematol, 190(1):e1-e3. https://doi.org/10.1111/bjh.16798

Paneesha S, Pratt G, Parry H, et al., 2020. COVID-19 infection in therapy-naive patients with B-cell chronic lymphocytic leukemia. Leuk Res, 93:106366. https://doi.org/10.1016/j.leukres.2020.106366

Playe M, Siavellis J, Braun T, et al., 2020. FDG PET/CT in a patient with mantle cell lymphoma and COVID-19: typical findings. Clin Nucl Med, 45(7):e305-e306.
https://doi.org/10.1097/RLU.0000000000003113

Psaltopoulou T, Sergentanis TN, Pappa V, et al., 2020. The emerging role of convalescent plasma in the treatment of COVID-19. Hemasphere, 4(3):e409. https://doi.org/10.1097/HS9.0000000000000409

Rajkumar MCSV, Mikhail J, Mateos MM, et al., 2020. COVID-19 and multiple myeloma: frequently asked questions. https:// www.hematology.org/covid-19/covid-19-and-multiplemyeloma [Accessed on Aug. 1, 2020].

Raza A, Assal A, Ali AM, et al., 2020. Rewriting the rules for care of MDS and AML patients in the time of COVID-19. Leuk Res Rep, 13:100201. https://doi.org/10.1016/j.lrr.2020.100201

Scarfò L, Chatzikonstantinou T, Rigolin GM, et al., 2020. COVID-19 severity and mortality in patients with chronic lymphocytic leukemia: a joint study by ERIC, the European research initiative on CLL, and CLL campus. Leukemia, 34(9):2354-2363. https://doi.org/10.1038/s41375-020-0959-x

Shadman JBM, Hallek M, Brown J, et al., 2020. COVID-19 and CLL: frequently asked questions. https://www. hematology.org/covid-19/covid-19-and-cll [Accessed on Aug. 1, 2020].

Siegel RL, Miller KD, Jemal A, 2019. Cancer statistics, 2019. CA Cancer J Clin, 69(1):7-34. https://doi.org/10.3322/caac.21551

Sieni E, Pegoraro F, Casini T, et al., 2020. Favourable outcome of coronavirus disease 2019 in a 1-year-old girl with acute myeloid leukaemia and severe treatment-induced immunosuppression. Br J Haematol, 189(6):e222-e224. https://doi.org/10.1111/bjh.16781

Subspecialty Group of Hematology and Oncology, Society of Pediatrics of Hubei, 2020. Standardized management guideline for pediatric wards of hematology and oncology during the epidemic of coronavirus disease 2019. Chin $J$ Contemp Pediatr, 22(3):177-182 (in Chinese). https://doi.org/10.7499/j.issn.1008-8830.2020.03.001

Stock W, Patel A, O'Dwyer K, et al., 2020. COVID-19 and adult ALL: frequently asked questions. https://www. hematology.org/covid-19/covid-19-and-all [Accessed on Aug. 1, 2020].

Tallman M, Rollig C, Zappasodi P, et al., 2020. COVID-19 and acute myeloid leukemia: frequently asked questions. https://www.hematology.org/covid-19/covid-19-and-acutemyeloid-leukemia [Accessed on Aug. 1, 2020].

Terpos E, Ntanasis-Stathopoulos I, Elalamy I, et al., 2020a. Hematological findings and complications of COVID-19. Am J Hematol, 95(7):834-847. https://doi.org/10.1002/ajh.25829

Terpos E, Engelhardt M, Cook G, et al., 2020b. Management of patients with multiple myeloma in the era of COVID-19 pandemic: a consensus paper from the European myeloma network (EMN). Leukemia, 34(8):2000-2011. https://doi.org/10.1038/s41375-020-0876-z

Treon SP, Castillo JJ, Skarbnik AP, et al., 2020. The BTK inhibitor ibrutinib may protect against pulmonary injury 
in COVID-19-infected patients. Blood, 135(21):1912-1915. https://doi.org/10.1182/blood.2020006288

Wang DY, Guo JM, Yang ZZ, et al., 2020. The first report of the prevalence of COVID-19 in chronic myelogenous leukemia patients in the core epidemic area of China: multicentre, cross-sectional survey. medRxiv, reprint. https://doi.org/10.1101/2020.03.12.20034876

Wang XH, Fang XX, Cai ZX, et al., 2020. Comorbid chronic diseases and acute organ injuries are strongly correlated with disease severity and mortality among COVID-19 patients: a systemic review and meta-analysis. Research, 2020:2402961.

https://doi.org/10.34133/2020/2402961

Wang YD, Zhang SP, Wei QZ, et al., 2020. COVID-19 complicated with DIC: 2 cases report and literatures review. Chin J Hematol, 41(3):245-247 (in Chinese). https://doi.org/10.3760/cma.j.issn.0253-2727.2020.0001

Wiersinga WJ, Rhodes A, Cheng AC, et al., 2020. Pathophysiology, transmission, diagnosis, and treatment of coronavirus disease 2019 (COVID-19): a review. JAMA, 324(8):782-793. https://doi.org/10.1001/jama.2020.12839

World Health Organization, 2020. WHO coronavirus disease (COVID-19) dashboard. https://covid19.who.int [Accessed on Oct. 9, 2020].

Wu YL, Lin H, Xie Q, et al., 2020. COVID-19 in a patient with pre-existing acute lymphoblastic leukaemia. Br J Haematol, 190(1):e13-e15. https://doi.org/10.1111/bjh.16799

Xia JH, Tong JP, Liu MY, et al., 2020. Evaluation of coronavirus in tears and conjunctival secretions of patients with SARS-CoV-2 infection. J Med Virol, 92(6):589-594. https://doi.org/10.1002/jmv.25725

Yang KY, Sheng YH, Huang CL, et al., 2020. Clinical characteristics, outcomes, and risk factors for mortality in patients with cancer and COVID-19 in Hubei, China: a multicentre, retrospective, cohort study. Lancet Oncol, 21(7):904-913.

https://doi.org/10.1016/S1470-2045(20)30310-7

Zanoni L, Mosconi C, Cervati V, et al., 2020. [18F]-FDG $\mathrm{PET} / \mathrm{CT}$ for suspected lymphoma relapse in a patient with concomitant pneumococcal pneumonia during COVID-19 outbreak: unexpected SARS-CoV-2 co-infection despite double RT-PCR negativity. Eur J Nucl Med Mol Imaging, 47(8):2038-2039.

https://doi.org/10.1007/s00259-020-04838-3
Zhang XH, Song KD, Tong F, et al., 2020. First case of COVID-19 in a patient with multiple myeloma successfully treated with tocilizumab. Blood $A d v, 4(7): 1307-1310$. https://doi.org/10.1182/bloodadvances.2020001907

Zhao Y, Zhao WH, Wang AB, et al., 2020. First case of coronavirus disease 2019 in childhood leukemia in China. Pediatr Infect Dis J, 39(7):e142-e145. https://doi.org/10.1097/INF.0000000000002742

Zhou F, Yu T, Du RH, et al., 2020. Clinical course and risk factors for mortality of adult inpatients with COVID-19 in Wuhan, China: a retrospective cohort study. Lancet, 395(10229): 1054-1062. https://doi.org/10.1016/S0140-6736(20)30566-3

Zhou P, Yang XL, Wang XG, et al., 2020. A pneumonia outbreak associated with a new coronavirus of probable bat origin. Nature, 579(7798):270-273. https://doi.org/10.1038/s41586-020-2012-7

Zhu HH, Huang XJ, 2014. Oral arsenic and retinoic acid for non-high-risk acute promyelocytic leukemia. $N$ Engl $J$ Med, 371(23):2239-2241.

https://doi.org/10.1056/NEJMc1412035

\section{中文概要}

题 目: 应对恶性血液肿瘤在新型冠状病毒肺炎疫情中的 挑战

概 要: 新型冠状病毒肺炎 (COVID-19) 是一种由严重急 性呼吸综合征冠状病毒 2(SARS-CoV-2) 引起的 新型传染病。SARS-CoV-2 具有极强的传染性, 因此在引发流行病后又使其迅速升级为全球大 流行, 至今仍在部分国家迅速传播。在 COVID-19 的感染者中，存在肿瘤等慢性病或伴有相关合并 症的患者预后往往较差。同时, 由于恶性血液肿 瘤患者长期处于免疫抑制状态, 往往感染风险更 高且预后更差，所以十分值得我们关注。这篇综 述归纳并分析了恶性血液肿瘤患者合并 COVID-19 后的临床表现。此外, 归纳了疫情期间 恶性肿瘤的管理策略和感染后的综合干预措施, 旨在为临床提供指导。

关键词: 新型冠状病毒肺炎 (COVID-19) ; 恶性血液肿瘤; 免疫抑制；管理策略；治疗方案 